\title{
Implementasi Teknologi Biometrical Identification untuk Login Hotspot
}

\author{
Andika D.L. Tumuli ${ }^{1 *}$, Xaverius N. Najoan ${ }^{2}$, Alwin M. Sambul $^{3}$ \\ 1,2,3 Program Studi Teknik Informatika, Fakultas Teknik, Universitas Sam Ratulangi \\ 120216027@student.unsrat.ac.id ${ }^{1}$,xnajoan@unsrat.ac.id ${ }^{2}$, asambul@unsrat.ac.id ${ }^{3}$
}

\begin{abstract}
Abstrak- ABSTRAK
Seiring dengan berkembangnya teknologi dewasa ini, perusahaan-perusahaan yang sebelumnya melakukan absensi kehadiran secara manual atau masih menggunakan absen tertulis mulai digantikan secara elektronik. Salah satu metode absensi yang paling ampuh dan banyak digunakan adalah absensi dengan menggunakan sidik jari. Hal ini karena identifikasi jenis ini terbukti aman, nyaman dan ekonomis.

Sidik jari tidak hanya dapat digunakan sebagai absensi yang terjamin keamanan dan kenyamanannya, sidik jari juga mulai dimanfaatkan sebagai alat login dalam suatu aplikasi. Penelitian dengan judul "Implementasi Teknologi Biometrical Idenfication untuk Login Hotspot" ini mengembangkan sebuah metode untuk memanfaatkan sidik jari sebagai sarana dalam mengotentifikasi seseorang ketika melakukan aktivitas browsing atau menggunakan internet dengan wifi di tempat-tempat umum.

Implementasi atau penerapan teknologi biometrical identification bisa menjadi solusi untuk menjamin setiap orang yang ingin mengakses internet dengan aman, proses otentifikasi password wifi dengan cepat dan aman. Sistem yang diajukan peneliti adalah user yang sudah terdaftar sidik jarinya, meletakkan jari pada alat pemindai sidik jari dan secara otomatis akan muncul kode untuk login hotspot. Dengan sistem seperti ini user tidak perlu menunggu admin atau seseorang yang mengetahui password login hotspot untuk menanyakan password login hotspot lagi dan juga setiap user memiliki password tersendiri.
\end{abstract}

Kata kunci - hotspot, sidik jari, biometric.

\section{PENDAHULUAN}

Maltoni et al. (2003) menyatakan bahwa pengenalan biometrik atau disebut juga identifikasi biometrik merupakan pengenalan seseorang secara otomatis berdasarkan karakteristik unik dari fisiologis (bagian-bagian tubuh tertentu seperti sidik jari, wajah, retina) maupun perilakunya.Dalam sistem biometrik biasanya digunakan model verifikasi dan identifikasi.Sistem verifikasi membandingkan biometrik seseorang dengan satu biometrik acuan pada basisdata, yang diklaim milik orang tersebut. Sistem verifikasi menjawab pertanyaan "apakah ini biometrik saya?".

Sidik jari menjadi pilihan terbanyak dengan presentase pengguna sebesar 52\%. Hal ini karena identifikasi jenis ini terbukti paling aman, nyaman dan ekonomis. Aman, karena sidik jari tidak dapat dipalsukan, nyaman karena verifikasi mudah dilakukan, dan pengguna tidak perlu direpotkan karena kartu ketinggalan,hilang, rusak, dan ekonomis karena alat ini ditawarkan dengan harga yang kompetitif dan pengaplikasiannya menjadikan perusahaan dapat meminimalkan biaya seperti penerbitan kartu baru atau penggantian kartu rusak atau hilang dan sebagainya. Akurasi dalam melakukan identifikasi bergantung pada reliabilitas ciri yang diambil dari citra sidik jari. Jain (2003).

Wireless Fidelity (wifi) komunikasi nirkabel (wireless) telah menjadi kebutuhan dasar atau gaya hidup baru masyarakat informasi. Menurut Priyambodo, Wireless Fidelity (Wifi) adalah suatu standar jaringan tanpa kabel dengan komponen yang sesuai sehingga dapat terkoneksi ke jaringan.

Era globalisasi saat ini menuntut kita semua untuk melakukan kegiatan lebih cepat dengan tingkat keamanan yang tinggi, sama halnya dengan kebutuhan internet menggunakan koneksi wifi. Misalnya pada sebuah café yang memiliki pelanggan tetap, sistem untuk mendapatkan password wifi untuk login hotspot dengan cara pelanggan menunggu pelayan untuk menanyakan password hotspot yang berada dalam café tersebut. Di era saat ini teknologi yang dapat mempermudah pekerjaan manusia tidak dimanfaatkan dengan sebagaimana mestinya. Untuk itu, dibutuhkan suatu teknologi yang dapat melakukan proses mendapatkan password untuk login hotspot dengan cepat dan aman.

Implementasi atau penerapan teknologi biometrical identification bisa menjadi solusi untuk melakukan proses autentikasi password wifi dengan cepat dan aman. Sistem yang diajukan peneliti adalah user yang sudah terdaftar sidik jarinya, saat meletakkan jari pada alat pemindai sidik jari secara otomatis akan muncul kode untuk login hotspot. Dengan sistem seperti ini user tidak perlu menunggu admin atau seseorang yang mengetahui password login hotspot untuk menanyakan password login hotspot lagi dan juga setiap user memiliki password tersendiri, mempertimbangkan sidik jari manusia sedemikian uniknya sehingga tidak ada seorangpun yang memiliki sidik jari yang sama dengan orang lain sehingga sistem ini menjamin kecepatan proses, kemanan dan ketepatan.

\section{LANDASAN TEORI}

A. Biometrical/Biometrik

Menurut Dr.Ir. Eko Nugroho,MSi (2008) biometrik adalah studi untuk mengenali seseorang secara unik. Didukung faktor harga yang semakin terjangkau dan bisa diterapkan pada banyak sektor, teknologi ini akan menggusur kata sandi (password) ataupun kartu (misal credit card) sebagai alat autentikasi maupun identifikasi.Kemajuan pesat dalam jaringan komunikasi mapun mobilitas alat memang membutuhkan 
E-Journal Teknik Informatika Vol.12, No. 1 (2017), ISSN: 2301-8364

metode yang handal untuk mengidentifikasi seseorang. Cara yang dikembangkan ialah dengan menggunakan biometrik, yaitu suatu keadaan fisik tertentu ataupun suatu perilaku tertentu unik yang ada pada seseorang. Cara ini juga disebut cara “what you are” . Keunggulan biometrik adalah :

1. Biometrik tak dapat hilang (fisik) atau lupa (perilaku) kecuali karena trauma.

2. Biometrik sulit ditiru maupun juga diberikan ke orang lain.

Biometrik mengharuskan orang yang bersangkutan ada ditempat dimana dilakukan identifikasi.

\section{B. Pengertian Identifikasi}

Identifikasi adalah proses pengenalan, menempatkan obyek atau individu dalam suatu kelas sesuai dengan karakteristik tertentu. (Menurut JP Chaplin yang diterjemahkan Kartini Kartono yang dikutip oleh Uttoro 2008:8). Menurut Poerwadarminto (1976: 369) " identifikasi adalah penentuan atau penetapan identitas seseorang atau benda".

Berdasarkan pendapat para ahli di atas, dapat ditarik kesimpulan bahwa identifikasi adalah penempatan atau penentu identitas seseorang atau benda pada suatu saat tertentu.

\section{Hotspot}

Hotspot di mikrotik adalah sebuah sistem untuk memberikan fitur autentikasi pada user yang akan menggunakan jaringan. Untuk bisa akses ke jaringan, client diharuskan memasukkan username dan password pada login page yang telah disediakan.

Hotspot tidak hanya merujuk ke jaringan wireless saja. Fitur hotspot ini bisa diterapkan di semua tipe interface jaringan seperti ethernet base. Hotspot merupakan gabungan dari fungsi proxy, firewall, DNS, DHCP, dan lain-lain. Akan tetapi pada mikrotik telah diberikan bantuan berupa setup wizard untuk memudahkan pembuatan sebuah hotspot server.

\section{METODOLOGI PENELITIAN}

\section{A. Identifikasi Masalah}

Bagaimana mengimplementasi teknologi biometrical identification untuk mengidentifikasi dan mengautentikasi orang yang akan login hotspot?

\section{B. Pengumpulan Data}

Metode pengumpulan data yang digunakan peneliti pada penelitian ini terdiri dari :

\section{Studi Literatur}

Pada tahapan ini penulis mencari berbagai sumber literatur untuk mendukung ide peneliti dalam pembuatan sistem. Tinjauan pustaka didapat dari E-book, paper serta jurnal terkait dengan ide dari sistem yang akan dibuat kedepannya.

2. Analisa Kebutuhan

Pada tahapan ini peneliti memerlukan beberapa data dan informasi baik software maupun hardware untuk menunjang tahapan-tahapan yang akan dilakukan selanjutnya.

3. Perancangan Awal dan Membuat Prototype.

Tahapan ini peneliti melakukan perancangan awal mengenai sistem yang akan dikembangkan. Selanjutnya berdasarkan rancangan awal prototype mulai dikerjakan dalam terjemahan kode program.

4. Membuat Aplikasi dan Melakukan Uji Coba.

Pada tahapan ini peneliti mengimplementasikan perancangan dan kode program yang sesuai untuk aplikasi biometrical identification untuk Login Hotspot. Selanjutnya peneliti melakukan uji coba (test aplikasi) untuk memastikan apakah aplikasi sudah siap digunakan.

\section{Tahapan Pembuatan Konten}

1. Analisa Kebutuhan

Kebutuhan yang dilakukan peneliti dalam proses pembuatan aplikasi biometrical identification untuk login hotspot adalah pemindai sidik jari, sidik jari pengguna dan router.

2. Membuat prototype

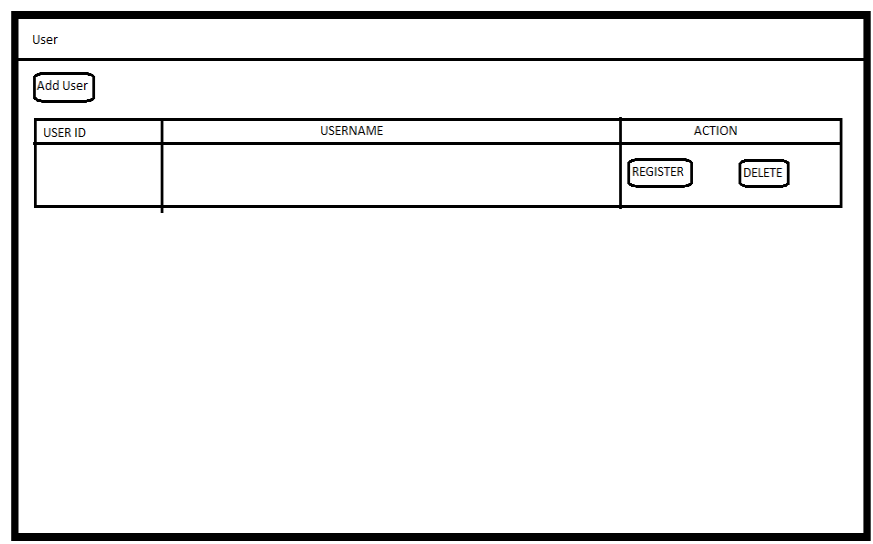

Gambar 1. Prototype Halaman Admin

\section{SELAMAT DATANG}

USERNAME

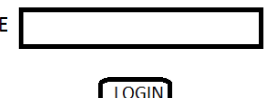

LOGIN

Gambar 2. Prototype Halaman Login

Pada halaman admin ini terdapat data user/pengguna, data device, $\log$ (daftar pengguna yang telah login). Pada tampilan awal aplikasi terdapat halaman user untuk login). 
E-Journal Teknik Informatika Vol.12, No. 1 (2017), ISSN: 2301-8364

3. Pembuatan Database

\begin{tabular}{|lllll|}
\hline$\#$ & Name & Type & Collation & Attributes Null Default Comments Extra \\
1 & device_name & $\operatorname{varchar}(50)$ & latin1_swedish_ci & No None \\
2 & sn & varchar(50) latin1_swedish_ci & No None \\
3 & vc & varchar(50) latin1_swedish_ci & No None \\
4 & ac & varchar(50) latin1_swedish_ci & No None \\
5 & vkey & varchar(50) latin1_swedish_ci & No None \\
\hline
\end{tabular}

Gambar 3. Tabel demo_device

Tabel demo_device adalah tabel yang digunakan untuk menyimpan data device yang diperlukan untuk penggunaan pemindai sidik jari agar dapat digunakan.

\begin{tabular}{|c|c|c|c|c|c|c|c|}
\hline & $\#$ & Name & Type & Collation & Attributes & Null & Default Comments Extra \\
\hline 0 & 1 & user_id & $\operatorname{int}(11)$ & & UNSIGNED & № & None \\
\hline 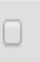 & 2 & finger_id & $\operatorname{int}(11)$ & & UNSIGNED & No & None \\
\hline 0 & 3 & finger_data & text & latin1_swedish_ci & & № & None \\
\hline
\end{tabular}

Gambar 4. Tabel demo_finger

Tabel demo_finger adalah tabel yang digunakan untuk menyimpan data sidik jari yang diperlukan untuk verifikasi login hotspot.

\begin{tabular}{|c|c|c|c|c|c|}
\hline$\#$ Name & Type & Collation & Attributes & Null Default & Comments Extra \\
\hline 0 $1 \log _{-}$time & timestam, & & 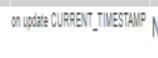 & No CURRENT_TMESTAMP & ONUPDAE CURRENT_TIMESTAMP \\
\hline [ 2 user name & vacharals & 7) lafin' suevish i & & No Nore & \\
\hline $0^{3}$ data & text & latin! swedish ci & & No Nore & sntpp time \\
\hline
\end{tabular}

Gambar 5. Tabel demo_log

Tabel demo_log yang terdapat adalah 3able yang digunakan untuk menyimpan informasi mengenai user yang telah login ke dalam hotspot beserta dengan waktu login.

\begin{tabular}{|c|c|c|c|c|c|c|c|}
\hline$\#$ & Name & Type & Collation & Attributes & $\mathrm{Null}$ & I Defau & ts Extra \\
\hline 01 & user_id & int(11) & & UNSIGNED & No & None & AUTO_INCREMENT \\
\hline $0^{2}$ & user_name & varcharl(5 & ) latin1_swedish_ci & & № & None & \\
\hline$\square^{3}$ & user_macadd & Varchat & latin1_swedish_ci & & Yes & NULL & \\
\hline
\end{tabular}

Gambar 6. Tabel demo_user

Tabel demo_user yang adalah tabel yang digunakan untuk menyimpan informasi mengenai username dan mac address pengguna hotspot.

4. Pembuatan Aplikasi

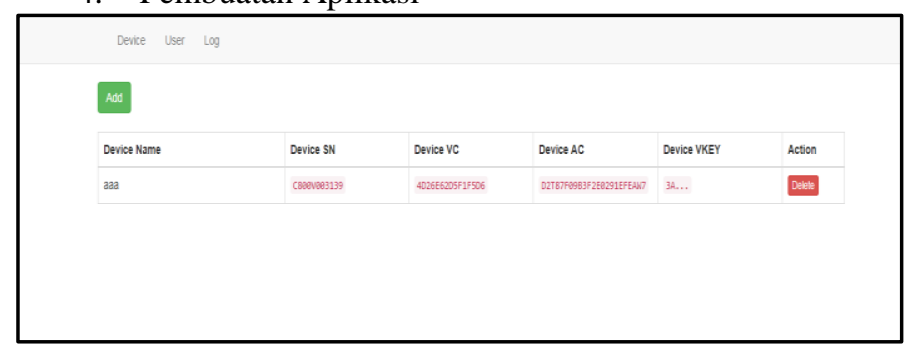

Gambar 7. Halaman Data Device
Tahapan pembuatan aplikasi dimulai dengan membuat halaman device bertujuan untuk mengetahui data dari device yang terdaftar. Data tersebut berupa serial number dan device itu sendiri. Hal ini diperlukan supaya software development kit yang telah diinstal dapat mengenal pemindai sidik jari yang telah terpasang pada perangkat komputer.

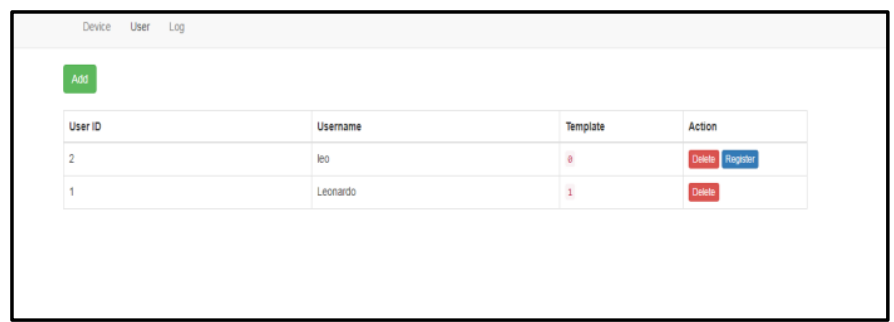

Gambar 8. Halaman Data User

Selanjutnya untuk halaman user, halaman ini bertujuan untuk mengetahui informasi mengenai user, sedangkan untuk admin bertujuan untuk menambahkan data user ke dalam database. Data yang diperlukan untuk membuat user baru adalah username, mac address, dan sidik jari.

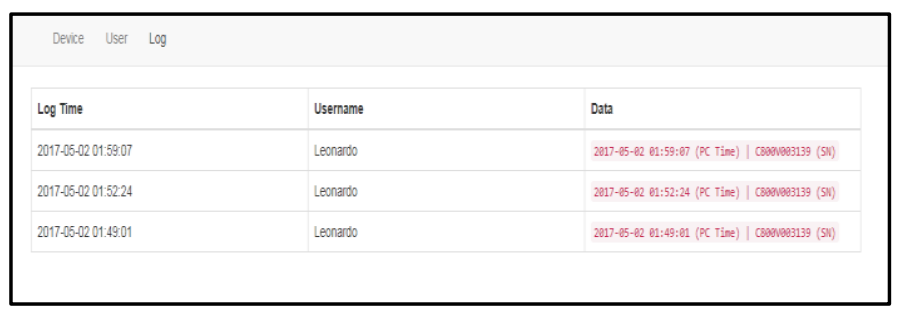

Gambar 9. Halaman Log

Halaman $\log$ berfungsi untuk menampilkan informasi mengenai user yang telah login ke dalam hotspot dan waktu login.

IV. HASIL DAN PEMBAHASAN

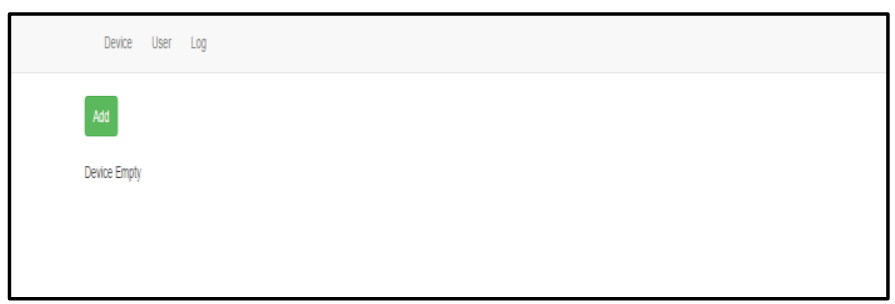

Gambar 10. Halaman Tambah Device

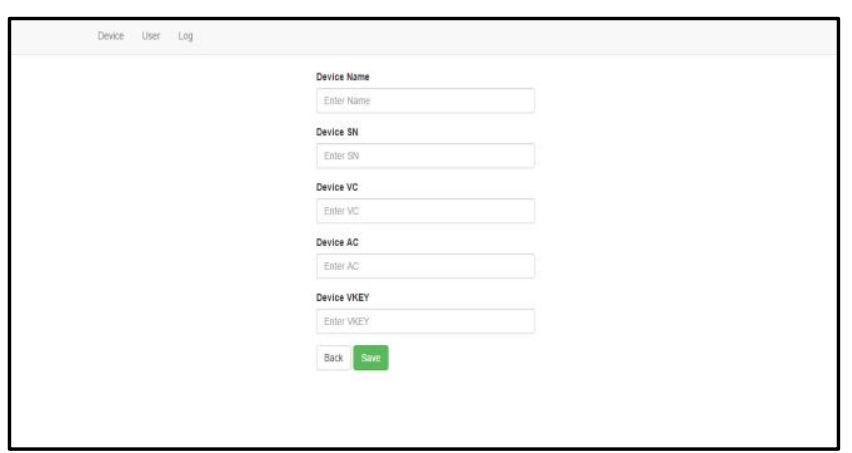

Gambar 11. Halaman Pengisian Data Device 
E-Journal Teknik Informatika Vol.12, No. 1 (2017), ISSN: 2301-8364

Pada gambar 11, merupakan halaman pengisian data device yang digunakan. Halaman ini hanya bisa diakses oleh admin, dimana admin akan menambahkan data serial number ke dalam database. Proses ini diperlukan agar driver fingerprint scanner, dapat mengidentifikasi scanner yang digunakan.

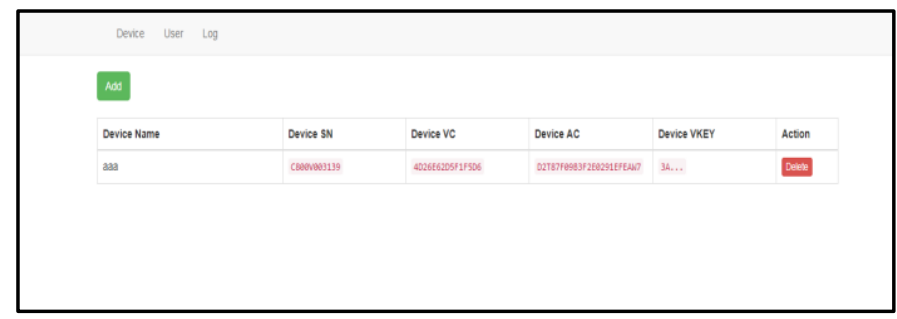

Gambar 12. Halaman Data Device Berhasil Ditambahkan.

Selanjutnya pada gambar 13, merupakan tampilan untuk menambahkan user ke dalam sistem. Pada halaman ini data yang diperlukan mencakup username, sidik jari dan mac address. Selanjutnya user diminta untuk menekan tombol register untuk memasukkan sidik jari ke dalam database.
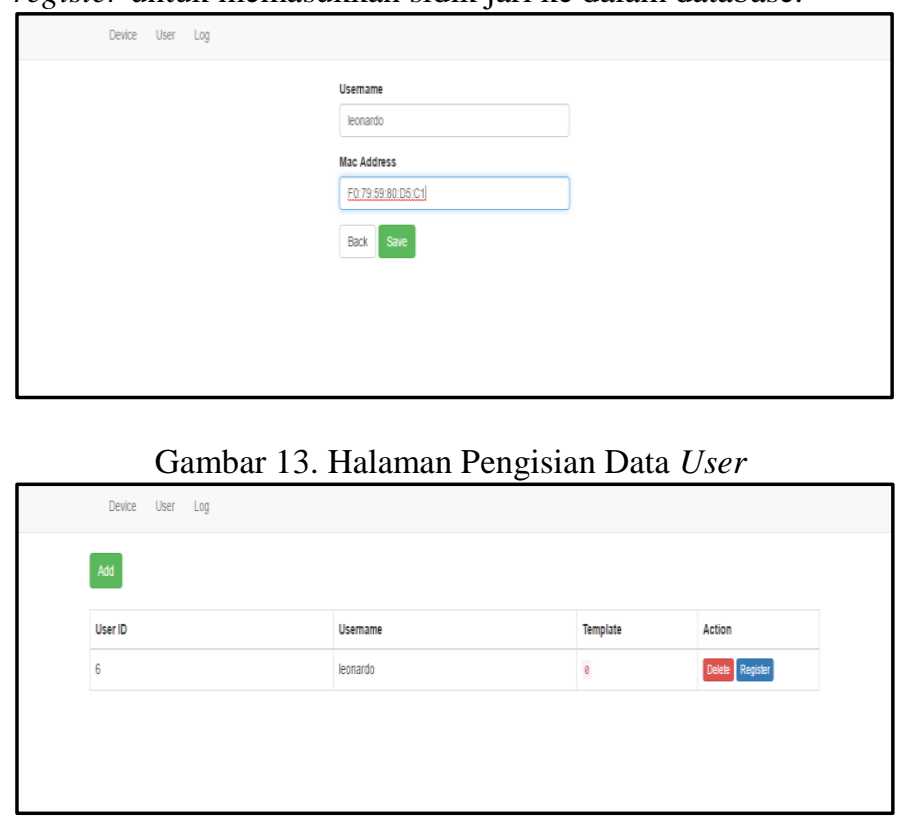

Gambar 14. Halaman Data User yang telah terisi

Setelah selesai dengan tahap registrasi user dapat menggunakan hotspot dengan cara login memakai sidik jari user sendiri.

\section{HOTSPOT LOGIN}

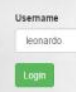

Gambar 15. Tampilan Login User
Tampilan pada gambar 15 merupakan halaman login user menampilkan form berisi username yang telah terdaftar pada database. Pada halaman ini, user diminta untuk meletakkan jari pada alat pemindai yang telah disediakan.

\section{HOTSPOT LOGIN}

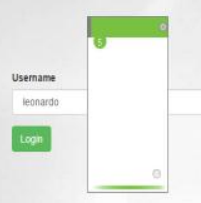

Gambar 16. Tampilan Pop-Up Login Sidik Jari

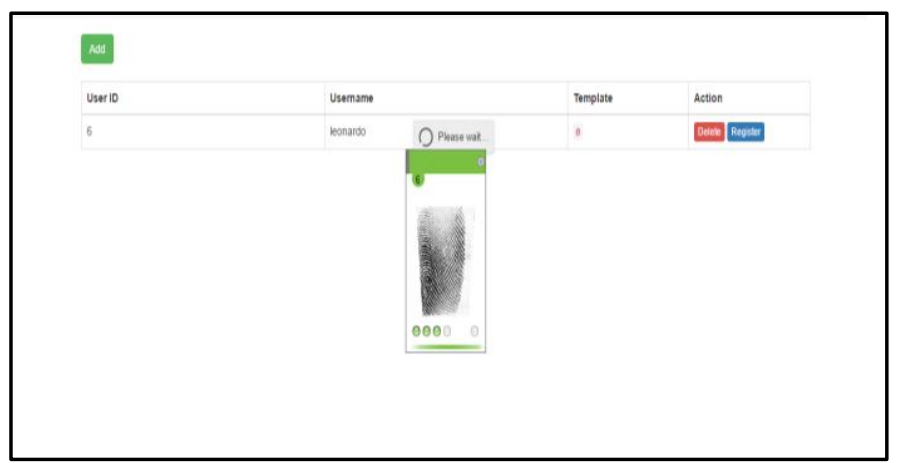

Gambar 17. Tampilan Pop-Up Meminta Sidik Jari User

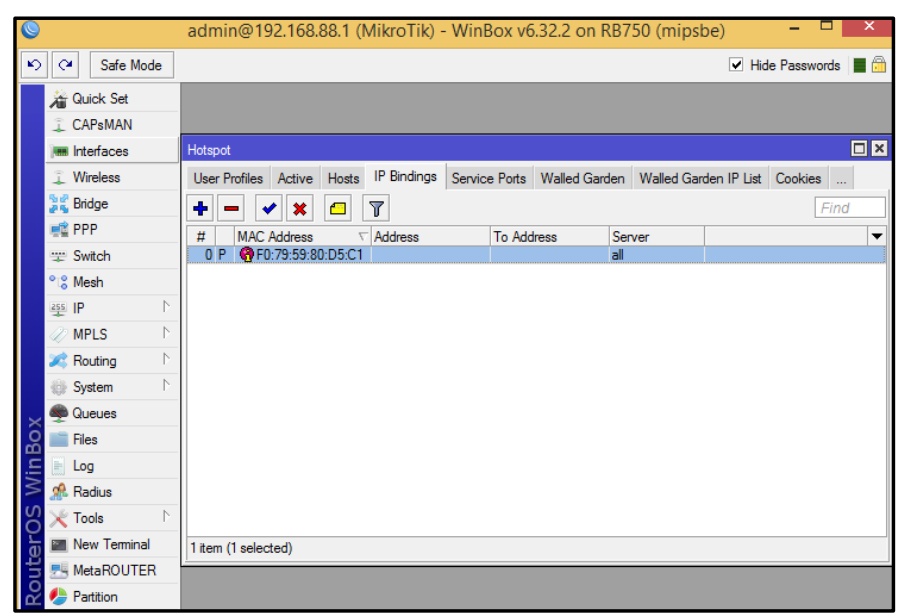

Gambar 18. Mac Address User Telah Masuk ke dalam Mikrotik

Gambar 18 merupakan tampilan mac address user yang telah masuk ke dalam tabel IP bindings router. Dapat dilihat bahwa user telah berhasil login dengan sidik jari, sehingga user dapat menggunakan internet. 
Tabel 1. Pengujian Pemindai Sidik Jari

\begin{tabular}{|c|c|c|}
\hline Gambar Pengujian & Keterangan & $\begin{array}{c}\text { Kecepatan Respon } \\
\text { Alat Pemindai Sidik } \\
\text { Jari }\end{array}$ \\
\hline & $\begin{array}{c}\text { Permukasan alat } \\
\text { pemindai sidik jari } \\
\text { bersih }\end{array}$ & $=1$ detik \\
\hline & 1 detik \\
\hline
\end{tabular}

\section{PENUTUP}

\section{A. Kesimpulan}

Penelitian ini telah berhasil membangun aplikasi untuk login hotspot dengan teknologi biometrical identification dengan kesimpulan bahwa aplikasi dapat dimanfaatkan sebagai alat untuk melakukan identifikasi dan autentikasi sidik jari bagi orang yang akan menggunakan hotspot, sehingga hanya orang dengan sidik jari yang telah terdaftar yang dapat login ke dalam hotspot. Alat pemindai sidik jari dengan tipe U are U 4500 merupakan alat yang efektif digunakan sebagai alat pemindai sidik jari, dimana pada beberapa contoh kasus seperti alat terhalang dengan debu dan plastik, alat tetap berfungsi dengan daya respon yang baik. Untuk contoh kasus alat terhalang dengan kertas dan tissue, alat pemindai tidak dapat merespon dengan baik karena cahaya yang dihasilkan pemindai tidak dapat menembus benda dengan ketebalan seperti kertas dan tissue.

\section{B. Saran}

Untuk mengembangkan aplikasi "Implementasi Teknologi Biometrical Identification untuk Login Hotspot" agar terlihat lebih baik dan dapat dimanfaatkan dengan sebagaimana mestinya, maka perlu dilakukan pengembangan lebih lanjut, antara lain sebagai berikut:

1. Aplikasi dapat dikembangkan dengan cara melakukan perubahan pada proses verifikasi sistem dari yang sebelumnya verifikasi sidik jari 1:1 menjadi verifikasi sidik jari $1: \mathrm{N}$.

2. Mengembangkan aplikasi agar dapat menyimpan banyak mac address device dalam 1 user.

\section{DAFTAR PUSTAKA}

[1] Maltoni, D., Jain, A.K., Maio, D.,Prabhakar, S., 2003, Handbook of Fingerprint Recognition, Springer Verlag,New York. [2] Quinn, C. (2000). Mlearning, Mobile Wireless in Your Pocket Learning

[2] Rina Candra Noor Santi.(2008).” Identifikasi Biometrik Sidik Jari dengan Metode Fraktal". Jurnal Teknologi Informasi DINAMIK Volume XIII, No.1,68-72.

[3] Jain, A.K, 2003, Multimodal User Interfaces: Who's the User?, Slides, http://biometrics.cse.msu.edu

[4]Dr.Ir.Eko Nugroho,MSi.(2008).Biometrik(Pengenalan) [Online].Available FTP: filest.distrodoc.com Directory: content/pdf/2014-11-27 File: pengenalan-biometrik.pdf.

[5] Pressman, S, Roger, Ph.D. 2010. "Rekayasa Perangkat Lunak Pendekatan Praktisi Edisi 7 (Buku 1)". Andi. Yogyakarta.

[6] Agus Supriyono, Imam Riadi.(2008)"Rancang Bangun Sistem Hotspot Menggunakan Captive Portal". Jurnal Sarjana Teknik Informatika Volume 1 Nomor 1,172-180.

[7] Bima Shakti Ramadhan Utomo, Denny Satria, Lulu Mawaddah Wisudawati."Peningkatan Keamanan Kartu Kredit Menggunakan Sistem Verifikasi Sidk Jari di Indonesia", in Prosiding Seminar Ilmiah Nasional Komputer dan Sistem Intelijen (KOMMIT 2012) Vol. 7, 18-19 September,2012.

\section{TENTANG PENULIS}

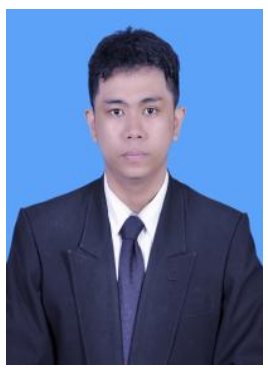

Sekilas dari penulis dengan nama Andika Dirga Leonardo Tumuli, anak pertama dari dua bersaudara. Lahir di Manado, tanggal 17 Agustus 1994. Dengan alamat sekarang Perum PDK , Kairagi 2. Sekolah pertama tempat belajar adalah SD YPPK Kristus Raja 1 Sorong. Kemudian melanjutkan pendidikan ke SMP YPPK Santo Don Bosco Sorong, dan melanjutkan pendidikan ke SMA N 1 Sorong. Pada tahun 2012, Penulis melanjutkan studi di Fakultas Teknik, Jurusan Elektro, Program Studi Informatika, Universitas Sam Ratulangi Manado. Kemudian pada tahun 2016 bulan Agustus penulis membuat skripsi demi memenuhi syarat Sarjana (S1) dengan penelitian berjudul "Implementasi Teknologi Biometrical Identification untuk Login Hotspot" dengan pembimbing I Xaverius Najoan, ST, MT. dan pembimbing II Alwin Melkie Sambul, S.T., M.Eng., Ph.D. Sehingga pada tanggal 11 Agustus 2017 penulis resmi lulus di Teknik Informatika Universitas Sam Ratulangi dan menyandang gelar sebagai Sarjana Komputer. 